\title{
PENINGKATAN KEPERCAYAAN DIRI SISWA TERHADAP MATEMATIKA DENGAN MENGGUNAKAN PENDEKATAN CTL (REACT)
}

\author{
Malik Ibrahim ${ }^{1}$ \\ 1 Universitas Nahdlatul Ulama NTB, Mataram, Indonesia \\ 1malikibrahim@unu-ntb.ac.id
}

\begin{abstract}
Abstrak
Penelitian ini menggambarkan efektivitas pendekatan CTL (REACT) untuk meningkatkan kepercayaan diri siswa terhadap pembelajaran matematika. Jenis penelitian ini adalah penelitian tindakan kelas (PTK). Subjek penelitian ialah siswa kelas VIII MTs Nurul Ihsan Sukarara tahun pelajaran 2017/2018 yang terdiri dari 29 siswa. Teknik analisis data yang digunakan adalah analisis deskriptif. Hasil penelitian menunjukkan bahwa nilai kepercayaan diri siswa terhadap matematika pada siklus I mencapai 10,3\% dalam katagori tinggi, 55,2\% dalam katagori sedang, dan 34,5\% dalam katagori rendah. Sedangkan, pada siklus II skor kepercayaan diri siswa terhadap matematika mencapai 6,9\% dalam katagori sangat tinggi, $72,41 \%$ dalam katagori tinggi, dan 20,69\% dalam katagori sedang. Penelitian ini memberikan kesimpulan bahwa terjadi peningkatan kepercayaan diri siswa terhadap matematika dengan menggunakan pendekatan CTL (REACT).
\end{abstract}

Kata kunci:, Kepercayaan Diri; Pembelajaran Matematika; Pendekatan CTL (REACT)

\begin{abstract}
The current study aims to describe the effectiveness of CTL approach (REACT) to improve students' self confidence in mathematics. It is a classroom action research (PTK). The subjects of the study were students of grade VIII MTs Nurul Ihsan Sukarara in the academic year 2017/2018 consisting of 29 students. Data analysis technique used is descriptive analysis. The findings show that students' confidence in mathematics in the first cycle reached $10.3 \%$ for high category, $55.2 \%$ for moderate, and $34.5 \%$ for low category. Meanwhile, in the second cycle students' self-confidence score on mathematics reached $6.9 \%$ for very high category, $72.41 \%$ for high category, and $20.69 \%$ for moderate. This study indicates that there is an increase of students' self confidence in mathematics due to CTL approach (REACT).
\end{abstract}

Keywords: Self-confidence; Mathematics Learning; CTL approach (REACT) 


\section{PENDAHULUAN}

Dalam upaya mewujudkan suasana belajar dan proses pembelajaran seperti yang tercantum dalam Undang-undang No. 20 tahun 2003 tersebut, pemerintah melalui Peraturan menteri pendidikan RI nomor 65 tahun 2013 tentang standar proses, mengemukakan karakteristik pembelajaran sesuai dengan Standar Kompetensi Lulusan (SKL), sasaran pembelajaran mencakup pengembangan ranah sikap, pengetahuan, dan keterampilan yang dielaborasi untuk setiap satuan pendidikan. Ketiga ranah kompetensi tersebut memiliki lintasan perolehan (proses psikologis) yang berbeda. Sikap diperoleh melalui aktivitas "menerima, menjalankan, menghargai, menghayati, dan mengamalkan". Pengetahuan diperoleh melalui aktivitas "mengingat, memahami, menerapkan, menganalisis, mengevaluasi, mencipta. Keterampilan diperoleh melalui aktivitas "mengamati, menanya, mencoba, menalar, menyaji, dan mencipta".

Upaya dalam mengembangkan ketiga ranah di atas yaitu sikap, pengetahuan dan keterampilan tersebut perlu dilakukan peningkatan kualitas pembelajaran baik dari segi penguasaan materi, penggunaan metode, penggunaan media maupun pengelolaan kelas yang kondusif. Ketiga ranah tersebut diaplikasikan pada semua jenjang pendidikan dan mata pelajaran yang tercantum dalam peraturan pemerintah.

Salah satu pembelajaran yang menjadi sorotan public saat ini adalah mata pelajaran matematika yang menurut beberapa siswa dianggap sebagai materi yang sulit. Matematika sebagai bekal siswa untuk memiliki kemampuan berpikir logis, analitis, sistematis, kritis, inovatif dan kreatif, serta kemampuan bekerjasama (Permendikbud No 68, 2013).

Pentingnya pembelajaran matematika diberikan disekolah menuntut pada pentingnya pengembangan prestasi belajar matematika siswa. Pengembangan prestasi tersebut bisa berupa prestasi belajar kognitif, afektif dan psikomotorik. Dengan tidak mengabaikan pengembangan prestasi 
belajar yang lain, peningkatan prestasi belajar kognitif merupakan salah satu komponen utama dalam melihat kualitas suatu pembelajaran.

Lebih lanjut dalam Peraturan Menteri Pendidikan Nasional No. 58 tahun 2013 tersebut juga disebutkan beberapa kompetensi yang harus dicapai dalam mata pelajaran matematika. Kompetensi tersebut diantaranya yaitu,

Memiliki sikap menghargai kegunaan matematika dalam kehidupan, yaitu memiliki rasa ingin tahu, perhatian, dan minat dalam mempelajari matematika, serta sikap ulet dan percaya diri dalam pemecahan masalah.

Tuntutan pentingnya pengembangan prestasi belajar matematika siswa di atas belum tersebar ke seluruh pelosok pelaku pendidikan, hal ini berdasarkan hasil observasi awal yang dilakukan di MTs Nurul Ihsan Sukarara, ditemukan bahwa rata-rata prestasi belajar matematika siswa pada tes middle semester ganjil tahun pelajaran 2017/2018 pada siswa kelas VIII belum memuaskan karena masih di bawah KKM yang ditetapkan di sekolah yaitu 75. Berdasarkan hasil wawancara dengan salah satu guru matematika di MTs Nurul Ihsan Sukarara ditemukan beberapa masalah pada pembelajaran matematika, yaitu: (1) prestasi belajar matematika pada middle semester dibeberapa kelasVIII belum mencapai KKM mata pelajaran matematika yaitu sebesar 80, (2) beberapa siswa belum memiliki rasa percaya diri yang kuat untuk mempelajari matematika karena masih menganggap matematika sebagai mata pelajaran yang sulit sehingga berdampak padaprestasi belajar matematika siswa, (3) keaktifan siswa untuk mengerjakan soal-soal latihan pada proses pembelajaran masih kurang, (4) pembelajaran di kelas masih didominasi oleh pembelajaran konvensional. Guru mengajar secara langsung dan siswa duduk memperhatikan penjelasan guru.

Masalah yang terjadi di atas diduga terjadi karena beberapa faktor baik faktor dari internal siswa itu sendiri ataupun faktor dari luar seperti 
pelaksanaan pembelajaran, keadaan sekolah dan lain sebagainya. Akan tetapi yang menjadi sorotan dalam hal ini adalah proses pembelajaran matematika dimana guru merasa kesulitan dalam melaksanakan pembelajaran yang variatif dan menyenangkan, oleh karena itu pembelejaran cenderung monoton dan kurang melibatkan aktifitas kooperatif siswa sehingga menyebabkan rasa percaya diri (self-confidence) mereka menjadi lemah untuk belajar matematika.

Memperhatikan standar kompetensi matematika untuk SMP/MTs dan kesenjangan yang terjadi di atas, salah satu aspek afektif yang perlu diperhatikan yakni aspek percaya diri (self-confidence) siswa. Menurut Fishbein \& Ajzen, "self-confident is a belief" (Parsons, Croft, \& Harrison, 2011). Keyakinan menurut Scoenfeld (Hannula, maijala, \& Pehkonen, 2004) adalah pemahaman dan perasaan individu yang membentuk cara dan konsep individu terlibat dalam perilaku matematika. Adapun self-confidence menurut Schunk (2012) adalah "the extent that one believes one can produce results, accomplish goals, or perform tasks comptenly".

Berdasarkan pernyataan ini kepercayaan diri dapat diartikan sebagai sebuah kepercayaan untuk bisa memberikan hasil, mencapai tujuan, atau melakukan tugas secara kompeten. Sejalan dengan pendapat di atas, Srivastava (2013) mengungkapkan bahwa orang yang percaya diri akan memiliki pandangan positif terhadap dirinya dan situasi yang sedang mereka alami. Merekapun percaya pada kemampuan mereka sendiri dengan alasan yang realistis, serta mereka akan mampu untuk melakukan apa yang mereka inginkan, rencanakan dan harapkan. Apabila harapan mereka tidak terwujud maka mereka terus berpikir positif dan menerima semua yang terjadi. Dalam sebuah penelitian diungkapkan bahwa kepercayaan diri memiliki hubungan positif terhadap prestasi belajar siswa (Komara, 2016).

Demi mewujudkan kompetensi-kompetensi yang disebutkan di atas, perlu adanya suatu strategi yang diterapkan pada proses pembelajaran matematika yang dapat meningkatkan rasa percaya diri siswa terhadap 
matematika sehingga berdampak baik terhadap prestasi belajar siswa. Strategi yang efektif dalam pembelajaran matematika antara lain dapat melatih siswa percaya diri berperan aktif terlibat secara langsung dalam proses pembeajaran matematika di kelas. Salah satu pembelajaran yang dapat melibatkan siswa secara aktif adalah pembelajaran kontekstual dengan REACT (Relating, Experiencing, Applying, Cooperating).

\section{LANDASAN TEORI}

Kepercayaan diri didefinisikan sebagai suatu keyakinan. Menurut Fishbein \& Ajzen (Parsons, Croft, \& Harrison, 2011) “self-confident is a belief”. Keyakinan menurut Scoenfeld (Hannula, maijala, \& Pehkonen, 2004) adalah pemahaman dan perasaan individu yang membentuk cara dan konsep individu terlibat dalam perilaku matematika. Kepercayaan diri yang diadopsi penulis adalah gabungan berdasarkan Fishbein \& Ajzen (Parsons, at. al, 2011) dan Scoenfeld (Hannula, at. al, 2004) bahwa kepercayaan diri adalah sebuah keyakinan yaitu pemahaman dan perasaan individu yang membentuk cara dan konsep individu terlibat dalam perilaku matematika, diantaranya yaitu; 1) kompetensi; 2) harga diri; dan 3) keyakinan tentang matematika.

Adapun self-confidence menurut Schunk (2012) adalah "the extent that one believes one can produce results, accomplish goals, or perform tasks comptenly". Berdasarkan pernyataan ini kepercayaan diri dapat diartikan sebagai sebuah kepercayaan untuk bisa memberikan hasil, mencapai tujuan, atau melakukan tugas secara kompeten. Sejalan dengan pendapat di atas, Srivastava (2013) mengungkapkan bahwa orang yang percaya diri akan memiliki pandangan positif terhadap dirinya dan situasi yang sedang mereka alami. Merekapun percaya pada kemampuan mereka sendiri dengan alasan yang realistis, serta mereka akan mampu untuk melakukan apa yang mereka inginkan, rencanakan dan harapkan. Apabila harapan mereka tidak terwujud maka mereka terus berpikir positif dan menerima semua yang terjadi. Kepercayaan diri sering kali dikaitkan dengan penghargaan diri (self-esteem). 
Hal ini diungkapkan oleh Azmandian (2010) bahwa "self-confidence is the manifestation and expression of self-esteem to the outside world". Ungkapan ini mengandung makna bahwa kepercayaan diri merupakan manifestasi dan ekspresi dari penghargaan diri pada dunia luar.

Secara umum kepercayaan diri diungkapkan oleh Harris \& Brown (AlHebaish, 2012) bahwa "general self-confidence is developed during te age of childhood and emerges from the accumulation of inter and intrapersonal experiences. Dapat dipahami bahwa secara umum kepercayaan diri dikembangkan pada masa kanak-kanak dan muncul dari kumpulan pengalaman baik dari dalam maupun luar pribadi.

Untuk membantu mengatasi masalah-masalah yang disebutkan di atas, maka diperlukan suasana belajar yang aktif, efektif, dan kreatif, menyenangkan serta memanfaatkan pengalaman dunia nyata siswa di kehidupan sehari-hari, agar siswa senantiasa meningkatkan rasa percaya diri dalam belajar matematika. Salah satunya adalah dengan menggunakan pembelajaran kontekstual yang merupakan alternatif pembelajaran yang potensial dalam meningkatkan kerjasama antar siswa dan diharapkan dengan kerjasama tersebut akan mampu meningkatkan prestasi belajar kognitif dan rasa percaya diri.

Pembelajaran kontekstual merupakan pembelajaran yang sangat dianjurkan oleh pemerintah mulai dari kurikulum 2004, 2006 dan 2013. Pembelajaran dengan kontekstual yaitu suatu konsep pembelajaran dimana guru menghadirkan situasi dunia nyata ke dalam kelas dan mendorong siswa membuat hubungan antara pengetahuan yang dimilikinya dengan penerapannya (Mendikbud, 2013). Definisi tentang pembelajaran kontekstual (CTL) sangat erat kaitannya dengan proses belajar mengajar menggunakan pengalaman dunia nyata. CTL membuat siswa mampu menghubungkan isi dari subjek-subjek akademik dengan konteks kehidupan sehari-hari. Pembelajaran dengan CTL dapat membantu siswa untuk belajar sesuai dengan tingkat berpikirnya. Mereka akan belajar berdasarkan 
Ibrahim, M. (2018). PENINGKATAN KEPERCAYAAN DIRI SISWA TERHADAP MATEMATIKA DENGAN MENGGUNAKAN PENDEKATAN CTL (REACT). Jurnal Tatsqif, 16(1), 42-64. Retrieved from http://journal.uinmataram.ac.id/index.php/tatsqif/article/view/133

pengetahuan yang telah mereka miliki sebelumnya. Pembelajaran kontekstual merupakan konsep belajar yang membantu guru mengaitkan antara materi yang diajarkan dengan situasi dunia nyata siswa dan mendorong siswa membuat hubungan antara pengetahuan yang dimilikinya dengan penerapannya dalam kehidupan sehari-hari (Berns \& Erickson, 2001).

Pembelajaran kontekstual didasarkan pada hasil penelitian John Dewey tahun 1916 yang menyimpulkan bahwa siswa akan belajar dengan baik jika apa yang dipelajari terkait dengan apa yang telah diketahui dan terkait juga dengan kegiatan atau peristiwa yang terjadi di sekelilingnya (Hosnan, 2014). Pembelajaran kontekstual memiliki tujuan utama yaitu membantu para siswa dengan cara yang tepat untuk mengaitkan makna pada pelajaran akademik mereka. CTL membuat siswa mampu menghubungkan subjek-subjek akademik mereka dengan konteks kehidupan sehari-hari (Johnson, 2009).

Pembelajaran matematika melalui CTL dilaksanakan dengan mengacu pada lima komponen, yaitu relating, experiencing, applying, cooperating, dan transfering yang dikenal dengan REACT (Crawford, 2001). Semua komponen tersebut diturunkan menjadi indikator-indikator pembelajaran dan kemudian dituangkan dalam sintaks pembelajaran, yaitu: (1) Guru menghubungkan konsep dengan pengetahuan yang dimiliki siswa. (relating); (2) Guru bersama siswa melaksanakan pembelajaran dengan bereksplorasi. (experiencing); (3) Guru bersama siswa menerapkan konsep yang dipelajari dengan dunia nyata. (applying); (4) Guru bersama siswa memecahkan masalah dengan berkelompok. (cooperating); (5) Mentransfer pemahaman yang telah dipelajari. (transfering). Satriani, et al. (2012) menjelaskan bahwa implementasi CTL, terutama dengan REACT (Relating, Experiencing, Applying, Cooperating, and Transferring) strategi di Amerika, suatu metode konstruktivisme, digunakan kepada para siswa untuk membentuk minat mereka, kepercayaan, dan menjadi suatu kebutuhan untuk pemahamannya. 


\section{METODE}

Subjek dalam penelitian ini adalah siswa kelas VIIIb MTs Nurul Ihsan Sukarara yang terdiri dari 29 siswa masing-masing terdiri dari 10 laki-laki dan 19 perempuan. Alasan pemilihan kelas VIIIb adalah karena dari 3 kelas yang ada di kelas VIII, kelas VIIIb merupakan kelas yang prestasinya paling rendah sehingga perlu dilakukan penelitian tindakan untuk mengatasi masalah tersebut. Penelitian ini merupakan penelitian tindakan kelas (PTK) yang terdiri dari empat tahap yaitu perencanaan (planning), tindakan (action), observasi (observing) dan refleksi (reflecting). Adapun teknik pengumpulan data dalam penelitian ini adalah dengan metode tes, angket dan observasi. Metode tes digunakan untuk mengumpulkan data prestasi belajar kognitif siswa, metode angket digunakan untuk mengumpulkan data kepercayaan diri siswa sedangkan metode observasi digunakan untuk mengumpulkan data keterlaksanan pembelajaran dengan menggunakan CTL (REACT) baik keterlaksanaan pembelajaran oleh guru maupun aktivitas siswa.

Teknik analisis data yang digunakan dalam penelitian ini adalah analisis deskriptif. Analisis deskriptif untuk mendeskripsikan keadaan siswa pada setiap siklus yang dilaksanakan. Pemberian angket pada siklus I dan siklus selanjutnya dibandingkan untuk mengetahui adanya peningkatan kepercayaan diri siswa atau tidak. Indikator keberhasilan setiap siklus adalah apabila tidak terdapat tingkat kepercayaan diri siswa pada kriteria rendah dan sangat rendah. Penskoran untuk angket kepercayaan diri siswa dilakukan menggunakan skala Likert dengan membuat interval menjadi 5 kriteria yaitu sangat tinggi, tinggi, sedang, rendah dan sangat rendah. Penskoran untuk skala kepercayaan diri pada penelitian ini memiliki rentang antara 30 sampai dengan 150, karena nilai terendah dalam penskoran angket adalah 30 dan nilai tertinggi adalah 150. Untuk menentukan kriteria hasil 
pengukurannya digunakan klasifikasi berdasarkan rata-rata ideal (Mi) dan standar deviasi ideal (Si). $\mathrm{Mi}=(30+150) / 2=90$ dan $\mathrm{Si}=(150-30) / 6=20$.

Tabel 1. Kategorisasi Kepercayaan Diri Siswa

\begin{tabular}{cccc}
\hline No & Interval & Skor $(\mathbf{X})$ & Kriteria \\
\hline 1 & $\mathrm{Mi}+1,5 \mathrm{Si}<\mathrm{X} \leq \mathrm{Mi}+3 \mathrm{Si}$ & $120<\mathrm{X} \leq 150$ & Sangat Tinggi \\
2 & $\mathrm{Mi}+0,5 \mathrm{Si}<\mathrm{X} \leq \mathrm{Mi}+1,5 \mathrm{Si}$ & $100<\mathrm{X} \leq 120$ & Tinggi \\
3 & $\mathrm{Mi}-0,5 \mathrm{Si}<\mathrm{X} \leq \mathrm{Mi}+0,5 \mathrm{Si}$ & $80<\mathrm{X} \leq 100$ & Sedang \\
4 & $\mathrm{Mi}-1,5 \mathrm{Si}<\mathrm{X} \leq \mathrm{Mi}-0,5 \mathrm{Si}$ & $60<\mathrm{X} \leq 80$ & Rendah \\
5 & $\mathrm{Mi}-3 \mathrm{Si} \leq \mathrm{X} \leq \mathrm{Mi}-1,5 \mathrm{Si}$ & $30 \leq \mathrm{X} \leq 60$ & Sangat Rendah \\
\hline
\end{tabular}

\section{HASIL DAN PEMBAHASAN}

\section{Hasil Penelitian}

a. Hasil Penelitian Siklus I

Pembelajaran pada siklus I berlangsung dalam dua pertemuan. Masing-masing pertemuan berlangsung 2 x 40 menit. Sedangkan evaluasi berlangsung selama 40 menit pada pertemuan kedua. Materi yang dibahas pada siklus I meliputi (1) mengenal unsur dan sifat kubus dan balok, (2) menentukan jaring-jaring kubus dan balok.

Pada pertemuan pertama materi yang diberikan adalah mengenal benda-benda menyerupai kubus dan balok dalam kehidupan sehari-hari. Mengidentifikasi unsur dan sifat kubus dan balok dalam matematika. Kegiatan pada siklus I terdiri dari 4 tahap yaitu sebagai berikut.

- Tahap Perencanaan Tindakan

Tahap perencanaan tindakan berupa (1) mengkaji langkahlangkah dalam pembelajaran CTL (REACT), (2) menyusun perangkat pembelajaran siklus I seperti silabus, RPP, dan LKS, (3) menyiapkan lembar observasi kegiatan guru dan siswa siklus I, (4) menyiapkan soal evaluasi siklus I beserta kunci jawabannya, (5) menyiapkan pedoman pensekoran soal evaluasi siklus I, (6) 
menyiapkan angket untuk mengukur kepercayaan diri siswa pada siklus I.

- Tahap Pelaksanaan Tindakan

Pertemuan pertama

Kegiatan pembelajaran siklus I pertemuan pertama dilaksanakan pada hari Rabu tanggal 08 November 2017 pukul 07.40 - 9.20. pada kegiatan tersebut perangkat pembelajaran berupa silabus, RPP, LKS dan tes individu sudah disiapkan. Selesai memberikan arahan kepada siswa, guru (peneliti) langsung meminta siswa untuk membentuk kelompok sendiri yang terdiri dari 6 kelompok sehingga masing-masing kelompok terdiri dari 5 siswa, pada kegiatan ini diharapkan siswa bisa melalui tahapan Experiencing dan Relating yaitu berinteraksi langsung dengan teman sejawat. Pada proses pembentukan kelompok tersebut, siswa masih ribut dan bingung dalam membentuk kelompok sehingga waktu yang dibutuhkan untuk membentuk kelompok cukup lama. Guru selanjutnya meminta siswa untuk menulis anggota kelompoknya pada kertas dan menyerahkannya kepada guru. Setelah itu guru memberikan soal pretes kepada siswa dan siswa secara antusias menjawab pretes tersebut secara individu, namun dalam mengerjakan pretes tersebut terlihat beberapa siswa masih berkeliaran dan mengobrol sementara beberapa siswa lain juga masih bingung dalam menyelesaikan soal tersebut, pelaksanaan pretest berlangsung selama \pm 40 menit.

Guru selanjutnya memberikan LKS 1 kepada masingmasing kelompok untuk diselesaikan dengan berdiskusdi pada kelompok masing-masing, tiap kelompok mengerjakan LKS 1 secara antusias dan kooperatif, kegiatan ini bertujuan agar siswa dapat melalui tahapan Applying dan Cooperating yaitu mengaplikasikan pengetahuan yang sudah dimiliki. Pada saat 
mengerjakan LKS 1 terlihat beberapa siswa bekerja sama dan saling tanya jawab pada saat berdiskusi, akan teteapi beberapa kelompok juga terlihat masih ribut dan membicarakan hal lain diluar materi pada LKS 1. Guru juga memberikan bimbingan terbatas kepada masing-masing kelompok jika ada hal yang belum jelas dalam pengerjaan LKS 1 tersebut. Siswa membutuhkan waktu yang cukup lama dalam mengerjakan LKS 1 tersebut sehingga belum ada satu kelompok yang menyelesaikan LKS 1 secara sempurna sehingga kegiatan presentasi kelompok tidak terlaksana dengan baik karena waktu pelajaran matematika sudah habis. Selanjutnya guru memberikan pengarahan kepada siswa untuk perbaikan-perbaikan pada pertemuan selanjutnya dengan mengurangi ribut dan lebih serius dalam bekerja sama pada masing-masing kelompok.

Pertemuan kedua

Kegiatan pembelajaran siklus I pertemuan kedua dilaksanakan pada hari Kamis tanggal 09 November 2017 pukul 07.40 - 09.20. pada kegiatan tersebut perangkat pembelajaran berupa silabus, RPP, LKS dan tes individu sudah disiapkan. Sebelum memulai pembelajaran, guru mengajak siswa untuk mempersapkan diri sebelum memulai pelajaran dengan mengajak siswa untuk tenang dan mempersiapkan bahan pembelajaran yang akan digunakan. Pada penyampaian apersepsi, guru mengingat materi sebelumnya dengan mengulas kembali contoh pada LKS pertemuan sebelumnya. Selanjutnya guru menyampaikan tujuan pembelajaran dengan menyebutkan kepada siswa apa yang bisa diperoleh siswa dalam pembelajaran tersebut. Selanjutnya guru memberikan informasi sedikit mengenai materi jaring-jaring kubus dan balok yang nantinya akan mereka kerjakan pada LKS yang sudah disiapkan. Sambil menggambar sebagian jaring-jaring 
di papan tulis, guru meminta siswa untuk bertanya jika ada yang belum jelas dari penjelasan materi tersebut. Terlihat beberapa siswa bertanya tentang materi yang belum jelas sehingga guru memberikan penjelasan lebih detail mengenai jaring-jaring kubus dan balok. Setelah itu, guru menginstruksikan kepada masingmasing kelompok untuk mendiskusikan LKS 2 yang sudah mereka dapatkan. Sebelum memulai diskusi, guru menyampaikan komponen-komponen penilaian dalam diskusi kelompok. Terlihat siswa berdiskusi secara tenang dan saling tanya jawab satu sama lainnya. Guru berkeliling untuk melihat proses terjadinya diskusi sambil memberikan bantuan terbatas kepada siswa dalam kelompok jika ada sesuatu yang kurang jelas dari LKS 2 tersebut. Setelah selesai mendiskusikan LKS 2, guru meminta beberapa kelompok untuk mempresentasikan hasil diskusi mereka di tempat masing-masing dengan cara berdiri, sementara kelompok lain memperhatikan presentasi kelompok tersebut, dalam presentasi tersebut tidak terjadi tanggapan dari kelompok lain.

Setelah selesai mempresentasikan hasil diskusi selanjutnya masing-masing siswa diminta untuk kembali duduk. Guru bersama seluruh siswa mengkroscek hasil kerja kelompok dan presentasi dari setiap kelompok serta membuat kesepakatan yang tepat mengenai materi yang dibahas. Setelah itu guru memberikan soal latihan yang harus dikerjakan secara individu oleh siswa. Siswa menggunakan waktu yang tersisa untuk menyelesaikan soal latihan yang diberikan guru secara individu, beberapa siswa masih sulit untuk menerima instruksi dari guru, terlihat sebagian besar siswa antusias meskipun beberapa masih seperti biasa. Setelah selesai mengerjakan soal tersebut, guru menutup pelajaran dan akan mengumumkan kepada siswa tentang ulangan atau uji kompetensi dari materi pada pertemuan pertama dan kedua. 
- Tahap Observasi

Berdasarkan lembar observasi dan diskusi dengan guru, terdapat beberapa kekurangan dan hal-hal yang mendukung dalam pelaksanaan sekenario pembelajaran siklus I. Adapun kekurangan-kekurangan pada proses pembelajaran berdasarkan lembar observasi, berupa (1) penggunaan alokasi waktu yang kurang baik sehingga beberapa kegiatan pembelajaran tidak terlaksana, (2) pelaksanaan presentasi kelompok tidak terlaksana pada pertemuan pertama dan kurang maksimal pada pertemuan kedua, (3) beberapa siswa tidak mendengarkan dan memperhatikan penjelasan guru, (4) siswa membentuk kelompok secara kurang tertib.

Setelah pembelajaran pada siklus I selesai, guru melakukan evaluasi dan memberikan angket kepercayaan diri siswa. Berikut disajikan rangkuman hasil evaluasi angket kepercayaan diri siswa.

Tabel 2. Hasil Evaluasi Kepercayaan Diri Siswa Siklus I

\begin{tabular}{lcc}
\hline \multicolumn{1}{c}{ Keterangan } & Jumlah & Persentase \\
\hline Sangat Tinggi & 0 & $0 \%$ \\
\hline Tinggi & 3 & $10,3 \%$ \\
\hline Sedang & 16 & $55,2 \%$ \\
\hline Rendah & 10 & $34,5 \%$ \\
Sangat Rendah & 0 & $0 \%$ \\
\hline
\end{tabular}

Berdasarkan tabel 2 di atas, terlihat bahwa kepercayaan diri siswa pada katagori tinggi memiliki persentase 10,3\%, katagori sedang memiliki persentase 55,2\% dan katagori rendah memiliki persentase 34,5\%. Karena masih terdapat kepercayaan diri siswa dalam kategori rendah, maka dilanjutkan ke siklus berikutnya.

- Tahap Refleksi 
Berdasarkan hasil observasi dan diskusi dengan observer, kekurangan-kekurangan yang terdapat pada siklus I akan dilakukan tindakan perbaikan pada siklus II berupa (1) merencanakan alokasi waktu yang lebih efektif, dan alokasi waktu untuk menyampaikan materi harus efisien, (2) mengoptimalkan pengelolaan kelas terutama saat berdiskusi. (3) mengajak siswa untuk lebih semangat dalam presentasi hasil diskusi kelompok, (4) mengajak siswa untuk membuat kesimpulan dari materi yang dipelajari.

b. Hasil Penelitian Siklus II

Proses pebelajaran pada siklus II berlangsung dalam dua pertemuan. Pertemuan berlangsung selama 2 x 40 menit. Sedangkan evaluasi berlangsung selama 40 menit pada pertemuan ketiga.

- Tahap Pelaksanaan Tindakan

Pertemuan pertama

Kegiatan pembelajaran siklus II pertemuan pertama dilaksanakan pada hari Selasa tanggal 14 November 2017 pukul 07.40 - 09.20. Pada kegiatan tersebut perangkat pembelajaran berupa silabus, RPP, LKS dan tes individu sudah disiapkan dan direvisi dari hasil refleksi pada siklus I.

Sebelum memulai pembelajaran, guru mengajak siswa untuk mempersiapkan diri dan mempersiapkan bahan-bahan yang akan digunakan dalam proses pembelajaran. Selain itu guru juga mengajak siswa untuk lebih tenang dalam mengikuti pembelajaran baik sebelum berkumpul dalam kelompok maupun saat kembali ketempat duduk masing-masing.

Proses pembelajaran dimulai dengan penyampaian apersepsi oleh guru dengan menyampaikan materi yang sebelumnya sudah dipelajari. Dalam kegiatan penyampaian apersepsi tersebut guru mengajak siswa untuk bertanya jika ada 
hal yang belum jelas terkait materi sebelumnya dan beberapa siswa bertanya mengenai unsur kubus dan balok.

Selanjutnya guru juga tidak lupa menyampaikan tujuan pembelajaran yang ingin dicapai dalam pembelajaran pada hari tersebut dengan mengaitkan materi dan kehidupan sehari-hari. Kegiatan selanjutnya yang dilakukan guru adalah memberikan informasi terkait materi yang akan dipelajari pada saat itu. Sebelum diskusi dimulai, guru menginstruksikan kepada seluruh siswa untuk bergabung kembali dengan kelompoknya, tidak lupa pula menyampaikan aturan-aturan dalam berdiskusi dan komponen penilaian dalam berdiskusi dan siswa yang sudah berkumpul degan anggota kelompoknya memperhatikan penjelasan tersebut.

Selanjutnya guru membagikan LKS 3 kepada masingmasing siswa dalam kelompok dan meminta siswa untuk menyelesaikan LKS 3 tersebut dengan berdiskusi dengan anggota kelompoknya. Saat mendiskusikan LKS 3 suasana kelas lebih kondusif meskipun terdengar suara-suara dialog antar siswa terkait dalam mendiskusikan LKS 3 tersebut. Guru juga berkeliling ke setiap kelompok untuk melihat proses jalannya diskusi dan memberikan bantuan terbatas kepada siswa yang merasa belum jelas dalam menyelesaikan LKS 3 tersebut.

Setelah semua kelompok selesai mengerjakan, selanjutnya guru meminta beberapa kelompok untuk mempresentasikan hasil diskusi mereka di depan kelas dan guru. Pada kesempaatan itu, guru memilih kelompok 3 saja yang mempresentasikan terlebih dahulu hasil diskusi mereka. Terlihat siswa memperhatikan presentasi dari beberapa kelompok tersebut, namun siswa masih sulit untuk menanggapi persentasi dari teman-temannya. 
Setelah kegiatan presentasi hasil diskusi tersebut, guru tidak lupa memberikan penghargaan berupa pujian kepada siswa yang sudah berani mempresentasikan hasil diskusi mereka dan mengajak siswa untuk lebih bersemangat lagi. Selanjutnya guru menuliskan latihan soal di papan tulis yang diselsesaikan secara individu oleh setiap siswa. Guru menggunakan waktu 15 menit untuk menyelesaikan soal latihan tersebut karena hanya terdiri dari 2 soal saja dan hasilnya siswa mengerjakan soal latihan tersebut sesuai waktu yang telah ditentukan. Selanjutnya guru mengajak siswa untuk membuat kesimpulan dari materi yang dipelajari pada hari tersebut dan menginformasikan kepada siswa bahwa proses pembelajaran berikutnya akan dilaksanakan dengan berdiskusi. Setelah itu guru menutup pembelajaran dengan doa dan mengucapkan salam.

\section{Pertemuan kedua}

Kegiatan pembelajaran siklus II pertemuan kedua dilaksanakan pada hari Rabu tanggal 15 November 2017 pukul 07.40 - 09.20. Pada pertemuan kali ini perangkat pembelajaran berupa silabus, RPP, LKS dan tes individu sudah disiapkan dan direvisi dari hasil refleksi pada siklus 1. Sebelum memulai pembelajaran, guru mengajak siswa untuk mempersiapkan diri dan mempersiapkan bahan-bahan yang akan digunakan dalam proses pembelajaran. Selain itu guru juga mengajak siswa untuk lebih tenang dalam mengikuti pembelajaran baik sebelum berkumpul dalam kelompok maupun saat kembali ketempat duduk masing-masing.

Proses pembelajaran dimulai dengan penyampaian apersepsi oleh guru dengan menyampaikan materi sebelumnya 
yaitu tentang jaring-jaring kubus dan balok. Dalam kegiatan penyampaian apersepsi tersebut guru sesekali bertanya kepada siswa tentang materi yang sebelumnya dusah dipelajari, guru juga menginstruksikan kepada siswa untuk bertanya jika ada hal yang belum jelas terkait materi sebelumnya. Selanjutnya guru juga tidak lupa menyampaikan tujuan pembelajaran yang ingin dicapai dalam pembelajaran pada hari tersebut.

Kegiatan selanjutnya yang dilakukan guru adalah memberikan informasi terkait materi yang akan dipelajari pada saat itu yaitu menentukan rumus luas dan volume kubus. Dalam penyampaian informasi tersebut, guru tidak lupa menjelaskan contoh menhitung luas dan volume kubus. Guru juga mengajak siswa untuk bertanya dan beberapa siswa mengangkat tangan dan bertanya kepada guru terkait dengan materi yang dipelajari.

Setelah pemberian informasi tersebut dirasa sudah cukup, guru menginstruksikan siswa berkumpul dengan anggota kelompoknya disertai dengan membawa bahan-bahan yang akan digunakan untuk berdiskusi nantinya. Sebelum diskusi dimulai, guru seperti biasa pada pertemuan sebelumnya tidak lupa menyampaikan aturan-aturan dalam berdiskusi dan komponen penilaian dalam berdiskusi dan siswa yang sudah berkumpul dengan anggota kelompoknya memperhatikan penjelasan tersebut.

Selanjutnya guru membagikan LKS 4 kepada masingmasing siswa dalam kelompok dan meminta siswa untuk menyelesaikan LKS 4 tersebut dengan berdiskusi dengan anggota kelompoknya. Guru berkeliling melihat proses jalannya diskusi dan memberikan bantuan terbatas kepada siswa yang merasa belum jelas dalam menyelesaikan LKS 4 tersebut. Waktu yang dibutuhkan untuk mendiskusikan LKS 4 tersebut tepat sesuai 
dengan waktu yang telah ditentukan, Masing-masing kelompok sudah selesai mendiskusikan LKS 4 dan selanjutnya guru meminta masing-masing kelompok untuk mempresentasikan hasil diskusi mereka. Pada saat persentasi kelompok, yang lain memperhatikan dan menyimak apa yang disampaikan oleh temannya sembari menyiapkan pertanyaan bila ada yang berbeda dengan hasil diskusi kelompok lain. Setelah kegiatan presentasi hasil diskusi tersebut, guru tidak lupa memberikan apresiasi kepada siswa yang telah mempresentasikan hasil diskusi mereka dan mengajak siswa untuk lebih bersemangat lagi. Selanjutnya guru memberikan soal yang diselesaikan secara indvidu dimana sebelumnya guru meminta siswa untuk kembali duduk dan berpisah dari anggota kelompoknya. Guru menggunakan waktu 15 menit untuk menyelesaikan soal tersebut karena hanya terdiri dari 2 soal saja. Selanjutnya guru mengajak siswa untuk membuat kesimpulan dari materi yang dipelajari pada hari tersebut dan menginformasikan kepada siswa bahwa proses pembelajaran berikutnya akan dilaksanakan tes evaluasi. Setelah itu guru menutup pembelajaran dengan doa dan mengucapkan salam.

- Tahap Observasi

Berdasarkan pengamatan peneliti, hasil observasi dan diskusi dengan observer, pada siklus II proses pembelajaran sudah berjalan sesuai dengan sekenario meskipun masih belum maksimal. Hasil dari evaluasi nantinya akan tergantung dari masing-masing individu. Adapun hal-hal yang mendukung proses pembelajaran pada siklus II adalah siswa dapat menentukan rumus luas dan volume kubus dan balok, siswa dapat menhitung luas dan volume kubus dan balok.

Tabel 3. Hasil Evaluasi Kepercayaan Diri Siswa Siklus II

\begin{tabular}{lcc} 
Keterangan & Jumlah & Persentase \\
\hline Sangat Tinggi & 2 & $6,9 \%$ \\
\hline
\end{tabular}




\begin{tabular}{lcc}
\hline Tinggi & 21 & $72,41 \%$ \\
\hline Sedang & 6 & $20,69 \%$ \\
\hline Rendah & 0 & $0 \%$ \\
\hline Sangat Rendah & 0 & $0 \%$ \\
\hline
\end{tabular}

Berdasarkan tabel 3 di atas, terlihat bahwa kepercayaan diri siswa pada katagori sangat tinggi memiliki persentase 6,9\%, katagori tinggi memiliki persentase $72,41 \%$ dan katagori sedang memiliki persentase 20,69\%.

- Tahap Refleksi

Pada siklus ini indikator kinerja yang peneliti tentukan sudah tercapai dari segi prestasi belajar kognitif dan kepercayaan diri siswa maka dapat dikatakan penelitian ini sudah berhasil, sehingga penelitian dicukupkan sampai siklus II.

\section{Pembahasan}

Penelitian tindakan kelas ini dilaksanakan sebagai upaya meningkatkan kepercayaan diri siswa pada mata pelajaran matematika pokok bahasan kubus dan balok dengan menerapkan pembelajaran CTL (REACT). Penelitian ini dilakukan dalam dua siklus berdasarkan alokasi waktu yaitu empat kali pertemuan. Siklus I terdiri dari dua pertemuan dan siklus II terdiri dari dua pertemuan, setiap siklus dilakukan evaluasi satu kali pertemuan.

Pelaksanaan siklus I untuk pertemuan pertama dan kedua dilaksanakan berdasarkan rencana pelaksanaan pembelajaran yang telah disusun sesuai dengan sintaks CTL (REACT). Setelah pelaksanaan pembelajaran sebanyak dua pertemuan, dilakukan evaluasi untuk siklus I dan pemberian angket kepercayaan diri siswa. Berdasarkan evaluasi siklus I diperoleh nilai rata-rata kelas sebesar 84,33 dengan persentase ketuntasan belajar 72,4\%. Nilai tertinggi yang diperoleh siswa adalah 100 
dan nilai terendah adalah 50. Dari 29 siswa hanya 8 siswa yang memperoleh nilai di bawah KKM dan sisanya sebanyak 21 siswa memperoleh nilai di atas KKM. Sedangkan untuk pemberian angket kepercayaan diri pada siklus I, 10,3\% dari 29 siswa memiliki rasa percaya diri dalam katagori tinggi, 55,2\% memiliki rasa percaya diri dalam katagori sedang dan 34,5\% memiliki rasa percaya diri dalam katagori rendah.

Hasil yang diperoleh pada siklus I masih tergolong cukup baik atau belum memenuhi target kinerja pada penelitian ini. Hal ini disebabkan oleh beberapa faktor yaitu sebagai berikut.

- Guru belum maksimal dalam menyampaikan tahapan Relating yaitu menyampaikan konsep-konsep materi dan menghubungkan materi yang dipelajari dengan materi yang sudah dipelajari.

- Penggunaan alokasi waktu yang kurang baik sehingga beberapa kegiatan pembelajaran tidak terlaksana dengan baik.

- Pelaksanaan tahapan Experiencing pada presentasi kelompok kurang maksimal dan masih ribut sulit untuk memperhatikan kelompok yang sedang persentasi.

- Beberapa siswa tidak mendengarkan dan memperhatikan penjelasan guru

- Tahapan Cooperating yaitu Kerjasama antar anggota kelompok masih terlihat minim, sebab sebelumnya belum pernah dilakukan pembelajaran kelompok.

- Tahapan Applying dan Transfering yaitu siswa tidak dapat menyelesaikan LKS 1 secara baik dengan menggunakan pengetahuan sebelumnya dari waktu yang disediakan guru.

Peneliti melakukan refleksi berdasarkan kekurangan pada siklus I di atas, dengan merencanakan tindakan sebagai berikut. 
- Guru lebih memprioritaskan kepada penguasaan kelas dan memotivasi siswa untuk berdiskusi lebih semangat lagi dari sebelumnya, terutama pada saat persentasi hasil diskusi kelompok.

- Merencanakan alokasi waktu yang lebih efektif, dan alokasi waktu untuk menyampaikan materi harus ditambah.

- Mengoptimalkan pengelolaan kelas terutama saat berdiskusi.

- Guru lebih mengaktifkan tanya jawab dengan siswa pada saat pemberian melaksanakan apersepsi.

- Mengajak siswa untuk membuat kesimpulan dari materi yang dipelajari.

Proses pembelajaran pada siklus II dilaksanakan seperti siklus I, tetapi guru melakukan perbaikan-perbaikan berdasarkan kekurangankekurangan yang ditemukan pada siklus I. Berdasarkan hasil evaluasi siklus II diperoleh nilai rata-rata 88,0 dengan ketuntasan belajar 89,66\%. Meningkatnya nilai ketuntasan ini disebabkan karena dari 29 siswa hanya 3 siswa yang memperoleh nilai kurang dari KKM yang telah ditetapkan, sedangkan sisanya sebanyak 26 siswa memperoleh nilai di atas KKM. Sedangkan untuk pemberian angket kepercayaan diri siswa pada siklus II, 6,9\% dari 29 siswa memiliki rasa percaya diri dalam katagori sangat tinggi, 72,41\% memiliki rasa percaya diri dalam katagori tinggi dan 20,69\% memiliki rasa percaya diri dalam katagori sedang. Peningkatan nilai rata-rata dan persentase ketuntasan pada siklus II terjadi karena pelaksanaan pembelajaran CTL (REACT) sudah berjalan sesuai dengan rencana yang telah disusun. Selain itu, guru juga mampu meminimalisir kekurangan dalam penguasaan kelas, sehingga pelaksanaan RPP dapat berlangsung lebih baik dibandingkan siklus I. Hal ini menunjukkan bahwa alokasi waktu dapat berjalan sesuai dengan yang telah direncanakan. Terlihat juga adanya peningkatan nilai rata-rata dari siklus I dan siklus II yaitu sebesar 17,25. Selain itu, peningkatan kepercayaan diri siswa juga terlihat dari perbandingan hasil penskoran angket pada siklus I dan sklus 
II yang mana untuk katagori sangat tinggi terjadi peningkatan sebesar 6,9\%, untuk katagori tinggi terjadi peningkatan sebesar 62,11\% sedangkan untuk katagori sedang terjadi penurunan sebesar 34,51\%. Terjadinya peningkatan nilai rata-rata dan kepercayaan diri siswa dapat dijadikan indikator keberhasilan penelitian sehingga dalam penelitian ini dikatakan berhasil. Oleh karena itu dapat dikatakan bahwa kepercayaan diri siswa pada materi kubus dan balok meningkat menggunakan pembelajaran CTL (REACT) pada siswa kelas VIII MTs Nurul Ihsan Sukarara Lombok Tengah.

\section{KESIMPULAN}

Berdasarkan hasil penelitian dan pembahasan, maka dapat disimpulkan bahwa kepercayaan diri siswa mengalami peningkatan untuk katagori sangat tinggi terjadi peningkatan sebesar 6,9\%, untuk katagori tinggi terjadi peningkatan sebesar 62,11\% sedangkan untuk katagori sedang terjadi penurunan sebesar 34,51\% dengan menerapkan pembelajaran CTL (REACT), Sehingga dapat dikatakan bahwa kepercayaan diri siswa terhadap matematika mengalami peningkatan secara signifikan pada materi kubus dan balok kelas VIIIb MTs Nurul Ihsan Sukarara Lombok Tengah.

\section{DAFTAR PUSTAKA}

Al-Hebaish, S.M. (2012). The correlation between general self-confidence and academic achievement in the oral persentation course. Theory and Practice in Language Studies, 2 (1), 60-65. Finland: Academy Publisher.

Azmandian, A. (2010). Think yourself successful: Rewire your mind become confident and achieve your goals. New York: The McGraww-Hill Companies, Inc.

Berns, R. G., \& Erickson, P. M. (2001). Contextual teaching and learning: Preparing students for the new economy. Journal of Research No. 5. (Online). Diakses 
dari http://www.cord.org/ uploadedfiles/NCCTE_Highlight05-Contextual Teaching Learning.pdf pada tanggal 27 Agustus 2014.

Crawford, M. C. (2001). Teaching contextually: Research, rationale and techniques for improving students motivation and achievement in mathematics and science. Waco: CCI Publishing, Inc.

Hannula, M.S., et al. (2004). Development of understanding and selfconfidence in mathematics; Grades 5-8. Proceedings of the $28^{\text {th }}$ Conference of the International Group for the Psychology of Mathematics Education, 3, 17-24.

Hosnan, M. (2014). Pendekatan saintifik dan kontekstual dalam pembelajaran abad 21. Bogor: Ghalia Indonesia.

Johnson, E.B. (2009). Contextual teaching and learning; Menjadikan kegiatan belajar mengajar mengasyikkan dan bermakna. Bandung: Mizan.

Komara, I. B. (2016). Hubungan antara Kepercayaan Diri dengan Prestasi Belajar dan Perencanaan Karir Siswa. Psikopedagogia 2016, 5 (1), 33-42.

Permendikbud. (2013). Menteri Pendidikan dan Kebudayaan RI No 65 tahun 2013, tentang standar proses.

. (2013). Menteri Pendidikan dan Kebudayaan RI No 68 tahun 2013, tentang kurikulum SMP-MTs.

Parsons, S., Croft, T., \& Harrison, M. (2011). Engineering students selfconfidence in mathematics mapped onto Bandura's self-efficacy. Engineering Education, 6 (1), 52-61.

Satriani, et al. (2012). Contextual teaching and learning approach to teaching writing. Indonesian journal of applied linguistics, 2 (1), 10-22.

Schunk, D. H. (2012). Learning theory (6 $6^{\text {th }}$ ed.). Boston: Pearson.

Srivastava, S. K. (2013). To study the effect of academic achievement on the level of self confident. J. Psychosoc. Res., 8 (1), 41-51. 